\title{
Short communication: Vocalization of the Long-eared owl Asio otus (Strigiformes, Strigidae) in the Middle Volga, Russia
}

\author{
ALEXEY ANDREYCHEV ${ }^{\bullet}$, ALEXANDER LAPSHIN, VYACHESLAV KUZNETSOV \\ Department of Zoology, National Research Mordovia State University. Bolshevistskaya street, 68, Saransk 430005, Russia. Tel./fax.: +7-342-322637, \\ •email: andreychev1@rambler.ru
}

Manuscript received: 10 October 2021. Revision accepted: 12 November 2021.

\begin{abstract}
Andreychev A, Lapshin A, Kuznetsov V. 2021. Short Communication: Vocalization of the Long-eared owl Asio otus (Strigiformes, Strigidae) in the Middle Volga, Russia. Biodiversitas 22: 5325-5330. Both daily and seasonal year-round vocalizations of the Long-eared owl (Asio otus) (Linnaeus, 1758) were recorded in the Middle Volga River region, Russia with the use of digital dictophones. Voice recorders were installed in the daytime for up to 5 days. The maximum duration of continuous operation of voice recorders was about 140 hours. By the time the previous recording was finished, we would arrive and move the recorder to a different location. The Long-eared owl can be classified as a moderately vocalizing bird, with calls recorded during 3 spring months. Peak activity is associated with pre-incubation and incubation periods. In the spring months, calls of the Long-eared owl were recorded from $16.37 \mathrm{~h}$ to $03.43 \mathrm{~h}$. In the spring, the Long-eared owl began to cry before sunset (from 1 hour 30 minutes to 3 hours 15 minutes) and after sunset (from 56 minutes to 3 hours 39 minutes). Vocalization started after sunset for an average of 50 minutes. Vocalization always ended before dawn (to $1 \mathrm{~h} 21 \mathrm{~min}$ ). Statistically significant differences in the duration of vespers and morning vocalizations were obtained with the use Mann-Whitney U test $(Z=-3.08$; $p<0.05)$.
\end{abstract}

Keywords: Asio otus, climatic factors, Long-eared owl, Middle Volga, Russia, vocalization

\section{INTRODUCTION}

Vocalization of different species of animals carries a lot of scientific information about various features of their biology and ecology. The song of many bird species is a signal that conveys information about individual qualities that play a relevant role in advertising territory ownership and mate attraction (Martinez and Zuberogoitia 2002; Lourenço et al. 2013; Burgos and Zuberogoitia 2020). The hoots of some owl species have been shown to confirm this assertion and there is evidence that individual recognition and variation among populations exist. Females and males react in a variety of ways to the hooting of intruders. Thus, while territory defense is cooperative for some species, males and females of other species respond exclusively to intruders of their own sex (Martinez and Zuberogoitia 2002).

Because vocalizations are used to estimate owl populations, it is important to identify environmental factors affecting owl calling (Moreno-Mateos et al. 2011; Yee et al. 2016; Worthington-Hill and Conway 2017; Fröhlich and Ciach 2018; Ševčík et al. 2019; Zuberogoitia et al. 2019; Orlando et al. 2020). Some bird species may develop behavioral responses to adapt song parameters to adverse weather conditions (e.g., heavy rain, strong wind and cold temperatures; Sharikov and Shekhovtsov 2013; Zuberogoitia et al. 2019; Clément et al. 2021; PérezGranados et al. 2021). From alien studies, we should note the successful work of Spanish zoologists on the Eagle-owl (Bubo bubo). For the Southwestern part of Spain, it is shown that the beginning and end of the sound activity of owls are timed to sunset and sunrise, respectively. The authors explain this circumstance from the position of good visual contact between individuals (Penteriani and Delgado 2019). Researchers highlight the influence of weather, climate, and trophic conditions on vocalization (Lehikoinen et al. 2011; Sharikov and Shekhovtsov 2013; Mikkola and Mikkola 2015). One of the interesting species is a bird of prey-the Long-eared owl, Asio otus.

The calls of the Long-eared owl and other owls are used in the classical version only for tracking when using the direction-finding method (Tome 1997; Zuberogoitia et al. 2020). In the Netherlands, the calls of Long-eared owls were recorded from January (van Manen 2000). Of undoubted interest, at what hours of the day do the owl most vocalize? As well as how vocalization changes by season and month. And also, what possible reasons can have an impact on this?

The research aims to determine the vocal activity of the Long-eared owl (daily and seasonal rhythm) and the possible influence of weather and climatic factors in the Middle Volga, Russia.

\section{MATERIALS AND METHODS}

Voice activity of the Long-eared owl was recorded year-round in three districts (Figure 1) of the Republic of Mordovia, Russia Federation $\left(53^{\circ} 38^{\prime}-55^{\circ} 11^{\prime} \mathrm{N}\right.$ and $42^{\circ} 11^{\prime}-$ 
$\left.46^{\circ} 45^{\prime} \mathrm{E}\right)$. The climate of the region is moderately continental with pronounced seasons throughout the year. The average annual air temperature varies from 3.5 to $4.0^{\circ} \mathrm{C}$. The average annual precipitation in the territory is $480 \mathrm{~mm}$.

We recorded the vocalization of the Long-eared owl, Bolshebereznikovsky (Parakino, Shugurovo, Kosogory, Sosnovyj Gart), Chamzinsky (Kirzhemany), Dubensky (Cheberchino) districts.

We recorded the voice activity of the Long-eared owl from March to December for five years (2015-2020). We used Olympus VN-416PC, VN-406PC, VN-712PC autonomous recording units. Recording units were installed in the daytime in each sample site and automatically recorded for up to 5 days. This technique of recording vocalization was tested by Eagle-owl (rare species for the region) (Andreychev et al. 2014, 2016, 2017; Lapshin et al.
2018), Ural owl (common species for the region) (Andreychev and Lapshin 2017) and underground mammals (Andreychev 2018, 2019, 2021; Andreychev et al. 2020). Totally, we set the recording units in six sample sites (Figure 1). The maximum duration of continuous operation of voice recorders was about 140 hours. By the time the previous recording was finished, we would arrive and move the recorder to a different location.

Since no individual differences in the vocalization of the Long-eared owl were revealed, we concentrated on the total sample. Registration of the activity of the Long-eared owl is, first of all, registration of the calls of males, as females shout less often and mainly with the male. Therefore, most of the material was obtained from male vocalization since they exhibit higher vocal activity than females. This is consistent with data from other researchers (van Manen 2000; Zuberogoitia et al. 2020).



Figure 1. Research areas (black asterisks) 
The resulting audio records were processed using the AIMP 1.75 (2007) and AUDACITY2.1.1 (2015) programs. We looked at the spectrograms (time on the $\mathrm{x}$-axis; frequency on the y-axis; amplitude on the z-axis visualized as a color) using the software. The purpose of the spectrograms was to more effectively (faster) identify the calls and easily check when the vocalizations started and ended.

We singled out the beginning and end of vocal activity in the evening, night and morning hours when analyzing the recordings. The beginning and end of vocal activity in the evening hours were determined in the period of two hours before and after sunset. The onset of vocal activity in the morning hours was determined two hours before and after sunrise. The beginning and end of nighttime activity were recorded in the day's remaining interval between sunset and sunrise. The duration of individual periods of vocalization was determined. When identifying the confinement of the beginning and end of calls, only those days were taken into account when the Long-eared owl was shouted in the interval up to 5 hours relative to sunset and sunrise, respectively. In the presence of calls, but their absence sooner or later than this interval from sunset or sunrise, these days were not taken into account. A comparison was made for the months and seasons of the year. Similarly, a possible dependence of vocalization on the phases of the moon was revealed. The possible influence on owl activity of weather conditions (temperature $\left({ }^{\circ} \mathrm{C}\right)$, force $(\mathrm{m} / \mathrm{s})$ and direction of the wind, precipitation izn the form of rain or snow, cloud cover $(\%)$, pressure $(\mathrm{mm} \mathrm{Hg})$, was revealed. These variables were measured daily. To characterize the climatic conditions, we used data from a weather station Bolshie Berezniki (Phase of the Moon 2021, rp5.ru 2021, Sun and Moon Wall Calendar 2021, Well and weather 2021).

Correlation analysis (rs-nonparametric coefficient Spearman) was used to identify the relationship between vocalization and variables. We tested the next aspects of vocalization: number of calls per day, start or end of calling time, and total length of calling time. All these variables were defined in the AUDACITY program. A comparison was made for the months and seasons of the year. Similarly, a possible dependence of vocalization on the phases of the moon was revealed. Correlation analysis (rsnonparametric coefficient Spearman) was used to identify the relationship between vocalization and parameters. A comparison of morning and evening vocalization was made using the non-parametric Mann-Whitney U-tests. Statistical calculations were performed using the AtteStat 8 (2002), Microsoft Office Excel, Microsoft Corporation (2003), and Past (Hammer et al. 2001)computer programs.

\section{RESULTS AND DISCUSSION}

During the research period, 78 sound recordings were obtained and processed, with a total length of about 6500 hours. A common variant of the vocalization of the Longeared owl in Mordovia is a series of calls. The frequency range of male calls was $200-300 \mathrm{~Hz}$. The intervals between individual screams were $2 \mathrm{~s}$. It turns out a measured «huhu-hu-hu-hu-hu». The female's similar sound response was rougher, hoarser, and much rarer than the male's. The frequency range of female calls was $300-400 \mathrm{~Hz}$. A single female call usually lasted $0.5-0.6 \mathrm{~s}$ and was issued unevenly. The intervals between individual calls were from 4 seconds or more (Figure 2).

Record time, $\mathrm{h}: \min : \mathrm{s}$

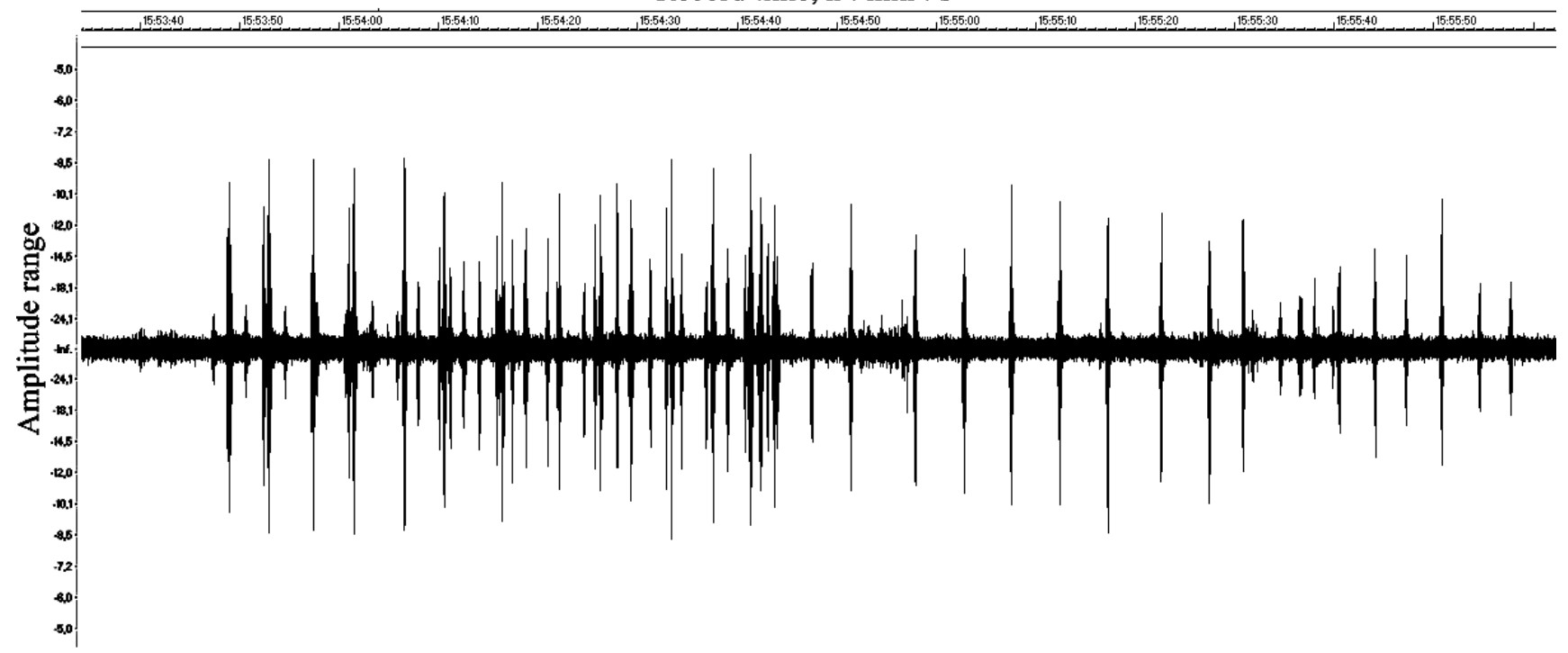

Figure 2. Oscillograms obtained by voice recorders vocalizations of Long-eared owl 


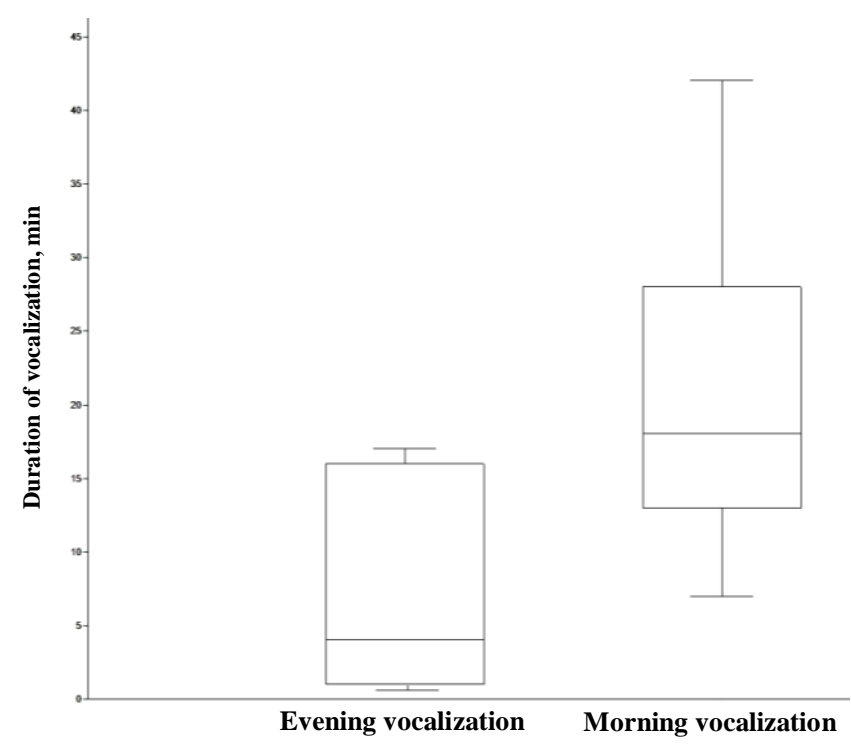

Figure 3. Ranges of the duration of evening and morning vocalization of the Long-eared owl based on materials for the spring period. Note: "striped box" is the median, the boundaries of the box are $25-75 \%$ quantiles, whiskers-minimum and maximum values

The vocal activity was recorded from March to May. The peak of vocal activity was recorded in April. In the spring months, calls of the Long-eared owl were recorded from $16.37 \mathrm{~h}$ to $03.43 \mathrm{~h}$. During this period, the Long-eared owl showed vocal activity during several hours from 1 to 6 h 42 min (village Kosogory-13.04.17) per night. The vocal activity showed a bimodal peak, one in the evening hours (before $00.00 \mathrm{~h}$ ) and the second before sunrise. Calls after $00.00 \mathrm{~h}$ were recorded less frequently, mainly in April.

A comparison of the entire evening and morning vocalization duration for the entire year using the Mann-
Whitney test revealed statistically significant differences between the first sample and the second $(\mathrm{Z}:-3.08$; $\mathrm{p}<0.05)$ (Figure 3 ). The duration of the evening vocalization of the Long-eared owl is significantly inferior to the morning vocalization.

As it was found out as a result of research, the vocalization of the Long-eared owl practically does not depend on the meteorological conditions of the environment. There is a statistically significant relationship between a binary variable of vocalization (yes-the owl calls are present or no-the owl calls are absent) and precipitation in the form of rain and snow (rs: $-0.34, \mathrm{p}: 0.01$ ). This is indirectly evidenced by the cessation of vocalization of the Long-eared owl with the beginning of rain. No statistically significant relationships were found with temperature (rs: 0.18 , p: 0.78), pressure (rs: 0.11, p: 0.66) and wind force (rs: -0.85 , p: 0.81 ). Vocalization was observed in the temperature range from -8 to $+19^{\circ} \mathrm{C}\left(+3 \pm 6.5^{\circ} \mathrm{C}\right.$; $\mathrm{CV}$ : $26 \%$ ). Calls of the Long-eared owl in the region were recorded at wind strength from 1 to $6 \mathrm{~m} / \mathrm{s}(3 \pm 1.11 \mathrm{~m} / \mathrm{s}$; CV: $233 \%$ ), at cloud cover from 10 to $100 \%$ (76 $\pm 0.89 \%$; $\mathrm{CV}: 29 \%)$, at pressure from 738 to $763 \mathrm{~mm} \mathrm{Hg}(750 \pm 2.02$ $\mathrm{mm} \mathrm{Hg}$; CV: $0.7 \%$ ). Calls were recorded equally in both the rising and waning phases of the moon. No calls were recorded during the full moon.

Comparison of the timing of the beginning of vocalization in the evening with sunset and its completion in the morning with sunrise did not reveal a statistically significant relationship. But, nevertheless, we consider it appropriate to give a general trend. In the spring, the Longeared owl began to cry before sunset (from 1 hour 30 minutes to 3 hours 15 minutes) and after sunset (from 56 minutes to 3 hours 39 minutes) (Figure 4). Vocalization started after sunset for an average 50 minutes. Vocalization always ended before dawn (to $1 \mathrm{~h} 21 \mathrm{~min}$ ) (Figure 5).

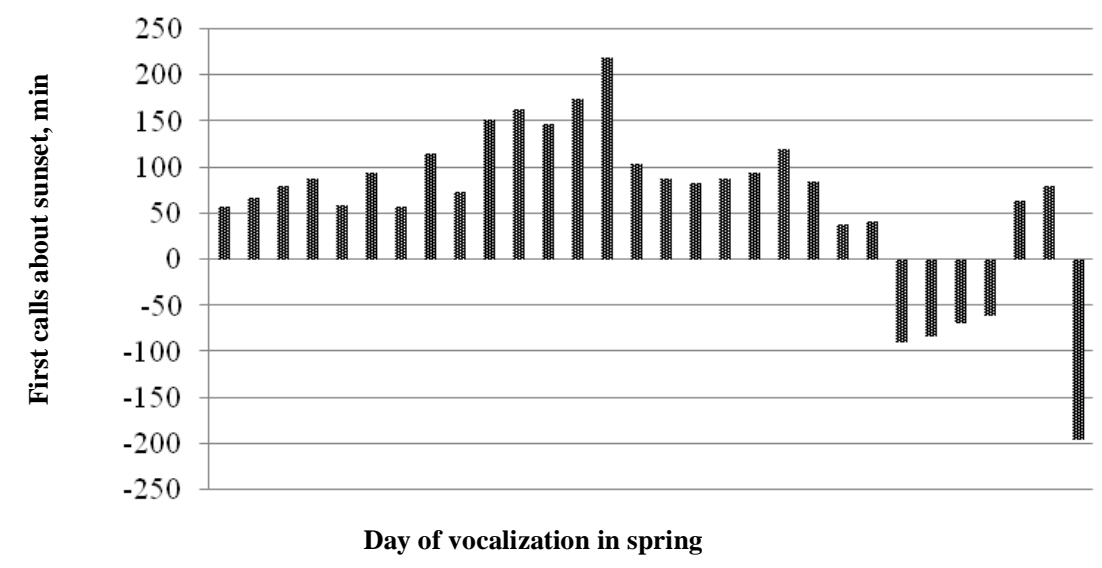

Figure 4. The timing of vocal activity of the Long-eared owl to sunset. Note: the number of columns corresponds to the number of days when the Long-eared owl began vocalization in the interval after 5 hours relative to sunset 


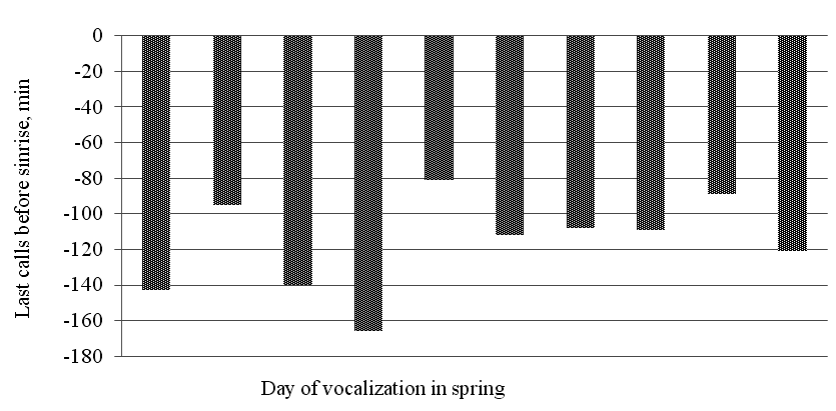

Figure 5. The timing of vocal activity of the Long-eared owl to sunrise. Note: the number of columns corresponds to the number of days when the Long-eared owl finished vocalization in the interval after 5 hours relative from sunrise

Comparing the results obtained by us with a few data on the vocal activity of the Long-eared owl in other regions, we should single out the general trend in the current timing. In Netherlands, where the calls of Longeared owl were recorded from January to April (van Manen 2000). In Mordovia, the vocalization of the Long-eared owl was recorded from March to May. We assume that the geographic latitude of the area inhabited by the Long-eared owl may be decisive in this difference. Climatic conditions exert indisputable influence. Our research covers the northern sections (approx. $54^{\circ} \mathrm{N}$ ), in Netherlands, these are the southern sections (approx. $52^{\circ} \mathrm{N}$ ), therefore vocalization of the Long-eared owl in Mordovia takes place somewhat later. The spring vocalization of the Long-eared owl is confirmed by data for Germany and Spain (Block 2009; Zuberogoitia et al. 2020).

In terms of vocal characteristics, the recorded calls of the Long-eared owl are similar to those recorded for other regions (Martínez et al. 2002; van Manen 2000; Block 2009; Pukinsky and Pukinskaya 2011). There are slight differences between Mordovia and Spain in daily activity with the general tendency of birds to start vocalizing after sunset. So vocalization in Mordovia began after sunset for an average 50 minutes. And in Spain, vocalization activity was often recorded during sunset (Martínez et al. 2002). A similar discrepancy in the vocalization of owls was noted earlier on the example of the Eagle Owl in Mordovia (Lapshin et al. 2018) and Spain (Penteriani and Delgado 2019).

Our results do not show statistically significant relationships between vocalization and many meteorological factors other than precipitation. However, their influence has a place to be on other features of the biology of the species. For example, for the city of Moscow, among weather factors, the most important influence on the dynamics of Long-eared owl was by snow cover and wind jointly, though the snow was undoubted of greatest significance. Air temperature and precipitation turned out to be almost of no importance for owl dynamics at the roosting site (Sharikov et al. 2014).

Of interest is the similarity of the Long-eared owl concerning the timing of vocalization to sunset and sunrise compared to other species of owls. For Eagle Owl in
Mordovia, evening calls were recorded, as a rule, 1 hour before sunset. The completion of the morning vocalization of the owl usually occurred 1.5 hours before sunrise (Lapshin et al. 2018). For the Tawny owl (Strix aluco) in the Moscow region, voice responses were recorded mainly after sunset, and for the Pygmy owl (Glaucidium passerinum) 1.5 hours before and after sunset (Sharikov and Shekhovtsov 2013). For the Blakiston's fish owl (Ketupa blakistoni) in Primorye, voice responses were recorded 20-40 minutes after sunset (Pukinsky and Pukinskaya 2011). Thus, we can say that the timing of vocalization to sunrise and sunset in different types of owls has a specific character. Spring and autumn distributions of calls of different species of owls by the time of day differ slightly.

Some differences in the number of calls of the Longeared owl per day in different regions can be explained by the results obtained by researchers in Spain on the example of the Eagle-owl. There is a lower intensity of vocalization of single males by season than males in pairs (Martinez and Zuberogoitia 2002). In areas with a high population density, calls are heard much more often in order to mark their sites from possible intruders.

\section{ACKNOWLEDGEMENTS}

We are grateful to V.I. Velmakin, G.V. Shkolov, I.V. Korotina, R.V. Tuboyakov, M.A. Alpeev, A.A. Shkulyov for support in carrying out of field studies.

\section{REFERENCES}

Andreychev AV. 2018. A new methodology for studying the activity of underground mammals. Biol Bull 45 (8): 937-943. DOI: 10.1134/S1062359018080022.

Andreychev AV. 2019. Daily and seasonal feeding activity of the greater mole-rat (Spalax microphthalmus, Rodentia, Spalacidae). Biol Bull 46 (9): 1172-1181. DOI: 10.1134/S1062359019090012.

Andreychev A. 2021. Activity of the European mole Talpa europaea (Talpidae, Insectivora) in its burrows in the Republic of Mordovia. For Ideas 27 (1): 59-67.

Andreychev A, Kuznetsov V, Lapshin A, Alpeev M. 2020. Activity of the Russian desman Desmana moschata (Talpidae, Insectivora) in its burrow. Therya 11 (2): 161-167. DOI: 10.12933/therya-20-801.

Andreychev AV, Lapshin AS. 2017. Quantitative and qualitative composition of diet of the Ural Owl, Strix uralensis (Strigidae, Strigiformes), in the central part of European Russia (the example of the Republic of Mordovia). Vestnik Zoologii 51 (5): 421-428. DOI: 10.1515/vzoo-2017-0050.

Andreychev AV, Lapshin AS, Kuznetsov VA. 2014. Food spectrum of the Eagle owl (Bubo bubo) in the Republic of Mordovia. Zool Zhurnal 93 (2): 248-258. DOI: 10.7868/S0044513414020032.

Andreychev AV, Lapshin AS, Kuznetsov VA. 2016. Breeding success of the Eurasian Eagle-owl (Bubo bubo) and rodent population dynamics. Biol Bull 43 (8): 851-861. DOI: 10.1134/S1062359016080045.

Andreychev AV, Lapshin AS, Kuznetsov VA. 2017. Techniques for recording the Eagle owl (Bubo bubo) based on vocal activity. Zool Zhurnal 96 (5): 601-605. DOI: 10.7868/S004451341705004X.

AIMP, AIMP DevTeam. 2007. [Electronic resource]. Access mode: http://www.aimp.ru/.

AtteStat 8, I.P. Gajdyshev. 2002. [Electronic resource]. Access mode: http://www.wosoft.ru/.

AUDACITY, Audacity Team. 2015. [Electronic resource]. Access mode: http://www.audacityteam.org/. 
Block B. 2009. Long-term trends in population density and reproductive success of Long-eared owl Asio otus in Brandenburg, Germany. Ardea 97 (4): 439-443. DOI: 10.5253/078.097.0406.

Burgos G, Zuberogoitia I. 2020. A telemetry study to discriminate between home range and territory size in Tawny Owls. Bioacoustics 29 (1): 109-121. DOI: 10.1080/09524622.2018.1555717.

Clément M, Shonfield J, Bayne EM, Baldwin R, Barrett K. 2021. Quantifying vocal activity and detection probability to inform survey methods for Barred Owls (Strix varia). J Raptor Res 55 (1): 45-55. DOI: 10.3356/0892-1016-55.1.45.

Fröhlich A, Ciach M. 2018. Noise shapes the distribution pattern of an acoustic predator. Curr Zool 64 (5): 575-583. DOI: 10.1093/cz/zox061.

Hammer $\varnothing$, Harper DAT, Ryan PD. 2001. Past: Paleontological statistics software package for education and data analysis. Palaeontologia

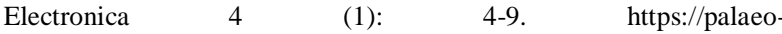
electronica.org/2001_1/past/past.pdf.

Lapshin AS, Andreychev AV, Kuznetsov VA. 2018. Daily and seasonal dynamics of the vocalization of the Eagle Owl (Bubo bubo, Strigiformes, Strigidae) in the central Volga region. Zool Zhurnal 97 (1): 77-88. DOI: 10.7868/S0044513418010075

Lehikoinen A, Ranta E, Pietiainen H, Byholm P, Saurola P, Valkama J, Huitu O, Henttonen H, Korpimaki E. 2011. The impact of climate and cyclic food abundance on the timing of breeding and brood size in four boreal owl species. Oecologia 165 (2): 349-1355. DOI: 10.1007/s00442-010-1730-1.

Lourenço R, Goytre F, del Mar Delgado M, Thornton M, Rabaça JE, Penteriani V. 2013. Tawny owl vocal activity is constrained by predation risk. J Avian Biol 44 (5): 461-1468. DOI: 10.1111/j.1600048X.2013.00157.x

Martinez JA, Zuberogoitia I. 2002. Factors affecting the vocal behaviour of Eagle Owls Bubo bubo: Effects of sex and territorial status. Ardeola 49 (1): 1-9.

Mikkola A, Mikkola H. 2015. Voice and daytime calling of Scops Owls (Otus scops). Ornis Hungarica 23 (2): 49-52. DOI: 10.1515/orhu2015-0014.

Microsoft Office Excel, Microsoft Corporation, 2003. [Electronic resource]. http://www.products.office.com/.

Moreno-Mateos D, Rey BJM, Pérez-Camacho L, Montaña EDL, Rebollo S, Cayuela L. 2011. Effects of land use on nocturnal birds in a Mediterranean agricultural landscape. Acta Ornithologica 46 (2): 173 182. DOI: $10.3161 / 000164511$ X625946.

Orlando G, Varesio A, Chamberlain D. 2021. Field evaluation for playback surveys: Species-specific detection probabilities and distance estimation errors in a nocturnal bird community. Bird Stud 68: 1-10. DOI: 10.1080/00063657.2021.1968790.
Penteriani V, Delgado MM. 2019. The Eagle Owl. Bloomsbury Publishing, NY.

Pérez-Granados C, Schuchmann KL, Marques MI. 2021. Vocal activity of the Ferruginous pygmy-owl (Glaucidium brasilianum) is strongly correlated with moon phase and nocturnal temperature. Ethol Ecol Evol 33 (1): 62-72. DOI: 10.1080/03949370.2020.1820582.

Phase of the moon 2021. Internet server 'Phase of the moon'. Available at: http://ru.astro-seek.com.

Pukinsky YB, Pukinskaya MV. 2011. Dueling and its possible functions in owls Strigidae of Russia and neighboring territories. Russian Ornithol J 20 (653): 867-891. [Russian].

Rp5.ru 2021. Reliable prognosis. Internet server 'The schedule of weather'. Available at: http://rp5.ru/.

Ševčík R, Riegert J, Šindelář J, Zárybnická M. 2019. Vocal activity of the Central European Boreal Owl population in relation to varying environmental conditions. Ornis Fennica 96 (1): 1-12.

Sharikov AV, Makarova TV, Ganova EV. 2014. Long-term dynamics of Long-eared owls Asio otus at a northern winter roost in European Russia. Ardea 101 (2): 171-176. DOI: 10.5253/078.101.0212.

Sharikov AV, Shekhovtsov SM. 2013. Seasonal and daily vocal activity of the Tawny Owl (Strix aluco) and Pygmy owl (Glaucidium passerinum) in Moscow region. Zool Zhurnal 92 (1): 68-76. DOI: $10.7868 / \mathrm{S} 0044513413010121$.

Sun and moon wall calendar 2021. Internet server 'The time of sunrise and sunset'. Available at: http://voshod-solnca.ru/.

Tome D. 1997. Timing of territorial vocal activity of the Long-eared owl (Asio otus) in Slovenia. Ardeola 44 (2): 227-228.

van Manen W. 2000. Trefkans bij het inventariseren van Ransuilen Asio otus in de broedtijd. Drentse vogels 13 (1): 27-29. [Dutch]

Well and weather 2021. Internet server. Available at: http://nuipogoda.ru/

Worthington-Hill J, Conway G. 2017. Tawny Owl Strix aluco response to call-broadcasting and implications for survey design. Bird Stud 64 (2): 205-210. DOI: 10.1080/00063657.2017.1315047.

Yee SA, Puan CL, Chang PK, Azhar B. 2016. Vocal individuality of Sunda scops-owl (Otus lempiji) in Peninsular Malaysia. J Raptor Res 50 (4): 379-390. DOI: 10.3356/JRR-15-76.1.

Zuberogoitia I, Burgos G, González-Oreja JA, Morant J, Martínez JE, Zabala AJ. 2019. Factors affecting spontaneous vocal activity of Tawny Owls Strix aluco and implications for surveying large areas. Ibis 161 (3): 495-503. DOI: 10.1111/ibi.12684.

Zuberogoitia I, Martínez JE, González-Oreja JA, de Buitrago CG, Belamendia G, Zabala J, Laso M, Pagaldai N, Jiménez-Franco MV. 2020. Maximizing detection probability for effective large-scale nocturnal bird monitoring. Divers Distrib 26 (8): 1034-1050. DOI: 10.1111/ddi.13075. 